\title{
STAN WIEDZY O POCZĄTKACH KLASZTORU CYSTERSÓW W HENRYKOWIE W DZIEJOPISARSTWIE PÓŹNEGO ŚREDNIOWIECZA ORAZ RENESANSU
}

\section{Wstęp}

Fundacje klasztorne jako wyraz pobożności i autorytetu władców, a także jako oznaka potęgi Kościoła pełniły ważną rolę w wizji dziejów kreowanej na kartach średniowiecznych oraz renesansowych dzieł historiograficznych. Wiadomości kronikarzy na temat procesu fundacji poszczególnych wspólnot monastycznych stanowią często cenne uzupełnienie klasztornych tradycji fundacyjnych.

W przypadku interesującego nas klasztoru cystersów w Henrykowie przekaz późnośredniowiecznych, a także renesansowych kronik przynosi dwie koncepcje dziejów opactwa ${ }^{1}$. Pierwsza z nich zgodna z klasztorną wizją początków przypisywała założenie Henrykowa śląskim książętom. Jej twórcą był kanonik brzeski Piotr z Byczyny - autor Chronica principum Poloniae ${ }^{2}$. Druga koncepcja, w której tytuł fundatora przynależał do notariusza Mikołaja, znalazła odzwierciedlenie na kartach Annales seu cronicae incliti Regni Poloniae Jana Długosza ${ }^{3}$. Wersja ta stała się niezwykle popularna w renesansowej historiografii

\footnotetext{
1 Problem początków opactwa w Henrykowie doczekał się szerokiego omówienia w literaturze przedmiotu: W. Pfizner, Versuch einer Geschichte des vormaligen Furstlichen Cisterziensers - Stiftes Heinrichau bei Munsterberg in Schlesien, s. 69-78; Monasticon Cisterciense Poloniae, t. 2, Katalog męskich klasztorów cysterskich na ziemiach polskich i dawnej Rzeczypospolitej, red. A.M. Wyrwa, J. Strzelczyk, K. Kaczmarek, Poznań 1999, s. 65-77; H. Grüger, Heinrichau. Geschichte eines Schlesischen Ziterzienserkloster 1227-1997, Köln 1978, s. 1115; idem, Das Patronatsrecht von Heinrichau. Zur 750-Jahrfeier der Klostergündung am 28. Mai 1977, „Cîteaux. Commentarii Cistercienses”, 28/1977, s. 26-47; J. Mularczyk, Jeszcze raz o fundacji klasztoru w Henrykowie, w: Acta Universitatis Wratislaviensis. Historia (dalej: AUWr), 33/1980, s. 181-198; H. Dąbrowski, Uformowanie sie wielkiej własności feudalnej cystersów w Henrykowie, „Roczniki Historyczne” 21/1956, s. 109-149; M. Cetwiński, Bóg, szatan i człowiek w Księdze henrykowskiej, „Nasza Przeszłość”83/1994, s. 85-95; A. Adamska, Founding a Monastery over Dinner: The Case of Henryków in Silesia (c. 1222-1228), w: Medieval Legal Process: Physical,Spoken and Written Performance in the Middle Ages, red. M. Mostert, P. Barnwell, Turnhout 2011, s. 212-230; Górecki P., Pamięć, forma literacka a tworzenie przeszłości: opat Piotr z Henrykowa jako dziejopis $i$ doradca prawny, „Roczniki Dziejów Społecznych i Gospodarczych”, 60/2000, s. 71-110; idem, An Interpreter of Law and Power in a region of mediewal Poland: Abbot Peter of Henryków and his Book, w: Building legitimacy:political discourses and form of legitimac, red. I. Alonso, J. Escalona, H. Kennedy, Lyon 2003, s. 263-290; P. Wiszewski, Życie zakonne w oczach elity intelektualnej Ślaska średniowiecznego i nowożytnego. Przemiany pewnego motywu, AUWr 63/2003, s. 183-216; idem, Zakonnicy i dworzanie - tradycje fundacji klasztorów w średniowiecznym dziejopisarstwie śląskim XIII-XV w., AUWr 153/2001, s. 179-198.

2 Kronika książą polskich(Chronica principum Poloniae), wyd. Z. Węclewski, Monumenta Poloniae Historica (dalej:MPH), t. III, Lwów 1878, s. 425-578.

3 Ioannis Dlugossii Annales seu Cronicae incliti Regni Poloniae. Liber 5,6, wyd. J. Dąbrowski, Warszawa 1973.
} 
i doczekała się kontynuacji w dziełach Macieja z Miechowa Chronica Polonorum ${ }^{4}$, Marcina Kromera De origine et rebus gestis Polonorum libri $X X X^{5}$ oraz Joachima Cureusa Gentis Silesiae Annales ${ }^{6}$.

Celem artykułu jest przedstawienie transmisji wiedzy na temat fundacji klasztoru henrykowskiego w obrębie historiografii od końca XIV aż do XVI w. Analiza obejmie zarówno problem narastania treści wokół fundacji Henrykowa, jak także aspekt jej kanonizacji w wieku XVI.

\section{Fundator}

Punktem wyjścia dla naszych rozważań będzie postać fundatora klasztoru w Henrykowie. Wedle klasztornej tradycji, której najpełniejszy obraz znajduje się w pierwszej części Księgi henrykowskiej spisanej przez opata Piotra w II poł. XIII w., klasztor powstał na skutek intencji notariusza księcia Henryka Brodatego Mikołaja, który postanowił przeznaczyć na rzecz fundacji całość swoich dóbr uzyskanych na służbie u księcia7. PPoproszony o wyrażenie zgody na fundację Henryk Brodaty wydał ją, jednak z jednym zastrzeżeniem, a mianowicie iż miano fundatora nie zostanie przypisane Mikołajowi, a książętom, szczególnie zaś synowi księcia - Henrykowi Młodszemu, który winien być przez mnichów uznany za założyciela opactwa $^{8}$. Również autor drugiej części Księgi henrykowskiej powstałej w I poł. XIV w. prawdziwym fundatorem opactwa nazywa Henryka Pobożnego9.

Książęcą metrykę klasztoru w Henrykowie podtrzymał autor Kroniki Książąt Polskich: Hic Henricus merito potest eciam dici fundator fuisse cenobii apud Heinrichaw, quoniam et si non ipse tamen promocione ipsius Nicolaus suus notarius idem fundavit monasterium, sicut narratur de eo ${ }^{10}$. Piotr z Byczyny wprowadził jednak poważną zmianę - za założyciela opactwa uznał wprawdzie księcia Henryka, ale w przeciwieństwie do Księgi henrykowskiej, chodziło mu o Henryka Brodatego. Z dopiski kronikarza kończącej cały ten fragment sicut narratur de eo można wnioskować, że informacja ta pochodziła z tradycji ustnej, prawdopodobnie dworu książąt legnicko-brzeskich, na których to zamówienie Piotr pisał swoje dzieło. Główny mecenas kroniki książę Ludwik legnicko-brzeski był propagatorem kultu św. Jadwigi Śląskiej, zaś w swoich fundacjach artystycznych oraz kościelnych odwoływał się do wielkiej przeszłości Śląska, która jednoznacznie wiązała się z postacią Henryka Brodatego ${ }^{11}$. Możliwe, iż kanonik chciał pokazać pewne paralele między Brodatym - księciem fundatorem klasztorów a Ludwikiem. Zresztą postać Henryka Pobożnego jako fundatora

\footnotetext{
4 Maciej z Miechowa, Chronica Polonorum, Kraków 1521.

5 Marcin Kromer, De origine et rebus gestis Polonorum libri XXX, Bazylea 1555.

6 Joachim Cureus, Gentis Silesise annales, complectes historiam de orgine, praecipuorum euentuum, qui in Eccelesia \& recitationem vsque ad necem Ludouici, Hungariae \& Bohemiae regis, acciderunt, Wittenberga 1571.

7 Księga henrykowska, wyd. R. Grodecki, Wrocław 1990.

8 Ibidem, s. 5-12.

9 Ibidem, s. 59.

10 Kronika Książąt Polskich, MPH t. III, s. 488.

11 W Kodeksie lubińskim Legendy obrazowej o św. Jadwidze, który powstał na zamówienie księcia Ludwika, Henryk Brodaty określony został „księciem całego Śląska”, co w realiach XIV w. kontrastowało z rozbiciem dzielnicowym Śląska, ukazując tym samym chlubną przeszłość tej dzielnicy. Z kolei w akcie fundacji kolegiaty brzeskiej można znaleźć informację, że władca dokonał swojego dzieła na wzór zmarłych książąt, z którymi łączyły go więzi pokrewieństwa; zob. A. Karłowska - Kamzowa, Fundacje artystyczne księcia Ludwika I Brzeskiego: studia nad rozwojem świadomości historycznej na Ślasku XIV-XVIII w., Wrocław 1970, s. 17 oraz s. 93-95.
} 
Henrykowa obecna jest jedynie w tradycji klasztornej. Jednak już w XIV w. w obrębie samego klasztoru jednorodność tradycji została złamana, coraz częściej jako fundatora wymieniano Henryka Brodatego, o czym świadczy chociażby inskrypcja z klasztornego kościoła datowana na rok 1355: Anno Domini MCCXXVII Monasterium hoc. Ord. Cisterciens. fundatum est ab Henrico Duce Silesiae ex Testamento D. Nicolai olim eiusdem Principis $N_{\text {otarii }}{ }^{12}$, a także zapiska z nekrologu henrykowskiego datowana na I poł. XIV w.: 2 XII Agetur anniversarium fundatorum huius monasterii, scilicet d. ducis Heynrici cum barba et filii eius necnon $d$. Nicolai ${ }^{13}$.

Przekonująca wydaje się jednak teza, że źródłem koncepcji, która przypisywała tytuł fundatora Henrykowi Brodatemu była Ordynacja biskupów wrocławskich ${ }^{14}$, która stanowi część Księgi henrykowskiej ${ }^{15}$. Wedle Romana Hecka Piotr z Byczyny nie wykorzystał w swojej kronice Księgi, a jedynie Ordynację ${ }^{16}$. Posiłkowanie się przez kronikarza Ordynacją potwierdza analiza treści i formy De institucione ecclesiae Wratislaviensis - ostatniej części dzieła Piotra z Byczyny ${ }^{17}$. Mianowicie w henrykowskim katalogu znajduje się informacja, że klasztor został ufundowany za rządów biskupa Wawrzyńca w 1227 r.: sub pio duce Heinrico cognomine cum barba ${ }^{18}$. Możliwe, że zapis ten niepoprzedzony badaniem treści Księgi henrykowskiej doprowadził kanonika Piotra do przeświadczenia, iż fundatorem opactwa był Henryk Brodaty.

Z drugiej strony w kronice Piotra z Byczyny widać charakterystyczną dla Księgi henrykowskiej złożoność problemu fundacji. Z jednej strony - zdaniem autora - książę może być słusznie uznany za fundatora opactwa, pomimo że nie założył klasztoru osobiście. Z drugiej strony notariusz Mikołaj, który za wsparciem księcia wprowadził fundację w życie, tytułu takiego nie posiadał. Warto porównać opis fundacji Henrykowa i Trzebnicy. W przypadku klasztoru trzebnickiego kronikarz kilkakrotnie na kartach swojego dzieła podaje informacje dotyczące konwentu mniszek, czy to w powiązaniu z pochówkami członków rodziny książęcej, czy też z emocjami, które śląscy Piastowie żywili do klasztoru ${ }^{19}$. Z kolei w interesującym nas fragmencie kroniki autor podkreślił bezpośrednie zaangażowanie i wysiłek

12 Inskrypcja z henrykowskiego klasztoru klasztornego zachowała się jedynie w odpisie nowożytnych historiografów, zob. Excerpta ex Nicolai Henelii ab Hennenfeld chronico ducatus Monsterbergensis et teritorii Francosteinensis, wyd. F.W. Sommersberg, w: Silesiacarum rerum Scriptores, t. 1, Breslau 1729, s. 142.

13 W.Wattenbach, Schlesische Nekrologien, 1. Nekrologium des Stifts Heinrichau, s. 302.

14 Pełna nazwa: Initium ordinationis Wrat(izlaviensis) ecclesie episcoporum, quorum nomina libello presenti subscribuntur; Liber fundationis claustri Sancte Marie Virginis in Henrichow, wyd. G.A. Stenzel, Breslau 1854, s. 123.

15 Księga henrykowska, s. 99-106.

16 R. Heck, Kronika książat polskich - metoda prezentacji dziejów, w: Dawna historiografia Śląsa. Materiaty z sesji naukowej odbytej w Brzegu w dniach 26-27 listopada 1977 r., red. K. Gajda, Opole 1980, s. 61-81.

17 Por.: Huius domini Laurentii episcopi tempore fundatum est claustrum nostrum de Heinrichow, anno domini MCCXXVII sub pio duce Heinrico, cognomine cum barbato. Eodem anno quinto kalendas Junii, intravit conventus hic in Henrichow (Liber fundationis claustri Sancte Marie Virginis in Henrichow, s. 126) oraz: cuius temporibus fundatum est monasterium Cisterciensis ordinis in Henrichow, per quedam Nicolaum, qui dicitur fuise notarius domini Henrici cum barba, ducis Wratislaviensis, cum adiutorio tamen eisudem domini sui duci. Conventus intravit idem monasterium sub duce predicto anno domini MCC XXII, V kalend. Juni (Kronika Książąt Polskich, s. 547). Można dostrzec, iż po wyrzuceniu fragmentu o Mikołaju, obie zapiski pod względem konstrukcji gramatycznej i kolejności przedstawiają dużą zbieżność

18 Liber fundationis, s. 126.

19 Kronika książąt polskich, s. 487-489. 
Henryka Brodatego w założenie Trzebnicy: quod magno studio pietatis pridem fundaverat et large dotaverat ${ }^{20}$. Czasowniki w trzeciej osobie 1.p. fundaverat, dotaverat jednoznacznie ukazują księcia jako fundatora. Z kolei w przypadku Henrykowa autor odstąpił od form osobowych na rzecz formy opisowej: merito potest eciam dici fundator fuisse, która nie oddaje tak silnie aktywnej roli księcia w fundacji opactwa. Również sformułowanie ,promotione ipsius" bez szerszego komentarza ze strony kronikarza powoduje, że przekaz dotyczący Henrykowa jest suchy, nie podkreśla stosunku księcia do fundacji, tak jak to ma miejsce w przypadku Trzebnicy.

Sprawa fundacji Henrykowa powraca raz jeszcze, jak już o tym wspomnieliśmy, w $D e$ institucione, gdzie autor stwierdza, że klasztor został założony przez Mikołaja z pomocą księcia Brodatego ${ }^{21}$. Natomiast konwent wszedł do Henrykowa: sub duce predicto. Wydaje się, że fragment ten należy rozumieć w kontekście pierwszej zapiski dotyczącej Henrykowa, mianowicie, że Mikołaj jedynie zrealizował fundację klasztoru, nie był zaś jego prawnym fundatorem.

W zupełnie innym świetle problem fundacji widział Jan Długosz, który informacje na temat Śląska czerpał w ogromnej części z dzieła Piotra z Byczyny, zarówno samej Kroniki Książąt Polskich, jak i De institucione ${ }^{22}$. Dla Długosza bez żadnej wątpliwości fundatorem Henrykowa był notariusz Mikołaj: Nicolaus siquidem de Henrichow ducis Wrathislaviensis Henrici cum barba secretorum notarius [...], de consensu et annuentia ducis Heinrici cum barba in villa patrimoni sui Henrichov [...] monasterium ordinis Czistercziensis fundat [... ${ }^{23}$. Mikołaj spełnił więc oczekiwane przez prawdziwego fundatora warunki: założył i uposażył klasztor. Podobną informację kanonik krakowski zamieścił także w Katalogu biskupów wrocławskich ${ }^{24}$. Znika całkowicie zróżnicowanie ról, które w założeniu klasztoru odegrali tak książę, jak i Mikołaj. Przekaz Długosza staje się jednowymiarowy, marginalizując postać księcia na rzecz Mikołaja zwanego felix fundator Henrykowa ${ }^{25}$.

W ślad za Długoszem bez żadnych zmian poszli Maciej z Miechowa ${ }^{26}$, Marcin Kromer ${ }^{27}$ oraz Joachim Curreus ${ }^{28}$. Miechowita dosłownie przejął fragment dotyczący Henrykowa, nie

\footnotetext{
20 Ibidem, s. 488.

21 Ibidem, s. 547.
}

22 A. Semkowicz, Krytyczny rozbiór dziejów polskich Jana Dlugosza (do roku 1384), Kraków 1887, s. 216. Na temat miejsca wspólnot monastycznych w dziełach Długosza wypowiadali się m.in.: P. Szczaniecki, Dlugosz o Tyńcu, „Zeszyty Naukowe Uniwersytetu Jagiellońskiego. Prace Historyczne”, 76/1985, s. 171-176; M. Starnawska, Wiadomości Długosza o templariuszach i joannitach, w: Kultura średniowieczna i staropolska. Studia ofiarowane Aleksandrowi Gieysztorowi w pięćdziesięciolecie pracy naukowej, red. D. Gawinowa et al., Warszawa 1991, s. 471476; B. Wojciechowska, Małopolskie klasztory cystersów w opinii Jana Dlugosza, w: Klasztor w kulturze średniowiecznej Polski, red. A. Pobóg-Lenartowicz, M. Derwich, Opole 1995, s. 195-200.

23 Ioannis Dlugossii Annales, s. 236.

24 Catalogus episcoporum Wratislaviensium, w: Joannis Dlugossi Senioris Canonici. Opera omnia, wyd. Alexander Przezdziecki, t.1, Kraków 1887, s. 461.

25 Ioannis Dlugossii Annales, s. 236.

26 A. Borzemski, Kronika Miechowity. Rozbiór krytyczny, Kraków 1890, s. 172.

27 L. Finkel, Marcin Kromer - historyk polski XVI wieku. Rozbiór krytyczny, Kraków 1883, s. 176; J. Radziszewska, Warsztat naukowy Marcina Kromera w jego dziele „,De origine et rebus gestis Polonorum”, w: Historia i wspótczesność. Z zagadnień historiografii od czasów antyku do XVI wieku, red. A. Kunisz, Katowice 1982, s. 131162.

28 M. Karpowska-Jarczyk, Wokót Gentis Silesiae annalis Joachima Cureusa. Z dziejów szesnastowiecznej historiografii śląskiej, Katowice 2011. 
dokonując znaczących zmian w tekście autora Roczników. Natomiast Kromer wprowadził głównie poprawki stylistyczne: Nicolaus Henrichovius [...], qui Henrico Barbato a secretis fuit, et ipse patrimonium suum omne Cistersiciensibus monachis, assentiente Henrico barbato donavit et extruncto ${ }^{29}$. Jedyną widoczną zmianą jest brak określeń tj. fundator, fundacja, co zastąpione zostało czasownikami donare (dawać) oraz extruir (budować). Jednak z kontekstu całej wzmianki jednoznacznie wynika, że dla Kromera to Mikołaj był założycielem Henrykowa, co zresztą nie jest dziwne, biorąc pod uwagę, że do przedstawienia dziejów Polski piastowskiej korzystał głównie z Długosza. W podobny sposób na temat fundacji opactwa henrykowskiego pisał Cureus: Nicolaus [...] cancellarius Heinrici Barbati [...] praedia sua, que habebat ditissima legavit ad cultum divinum, et extruxit coenobium amplium ${ }^{30}$.

\section{Rola książąt}

Pomimo że, jak wyżej stwierdziliśmy, jedynie Kronika Książąt Polskich podtrzymuje metrykę książęcej fundacji klasztoru w Henrykowie, to jednak w każdym z analizowanych przez nas dzieł, założenie klasztoru łączy się z osobą Henryka Brodatego. Z jednej strony poprzez przywołanie informacji o sprawowanej przez notariusza Mikołaja funkcji książęcego notariusza, $\mathrm{z}$ drugiej strony poprzez usytuowania fundacji opactwa w okresie rządów księcia.

Piotr z Byczyny zamieścił fragment dotyczący Henrykowa w akapicie poświęconym ostatnim latom panowania Henryka Brodatego, a także szczególnej pobożności księcia, która przejawiała się fundacją klasztoru cysterek w Trzebnicy oraz konwentu mnichów w Henrykowie. Wedle autora kroniki Henryk Brodaty miał wesprzeć starania notariusza Mikołaja, których celem była fundacja opactwa szarych mnichów: tamen promocione ipsius Nicolaus [...] idem fundavit monasterium ${ }^{31}$. Podobny passus znajdziemy w De institucione: Nicolaus [...] cum adiutorio tamen eiusdem domini suis duci ${ }^{32}$. Owo wsparcie księcia bliżej zresztą niescharakteryzowane miało być wedle kronikarza czynnikiem decydującym o uznaniu Brodatego za fundator klasztoru. Księga henrykowska nieco inaczej przedstawia rolę Henryka I. Po pierwsze podczas rozmowy Mikołaja z prepozytem Piotrem i archidiakonem Idzim na temat planowanej fundacji notariusz zaznaczył, że potrzebne jest uzyskanie zgody księcia: domini mei ducis consensus ${ }^{33}$. Także opis uczty w Henrykowie w 1222 r. dotyczy przede wszystkim uzyskania zgody księcia na założenie klasztoru. Zadanie to zostało powierzone biskupom: Wawrzyńcowi wrocławskiemu, Pawłowi poznańskiemu i Wawrzyńcowi lubuskiemu: Hic [Mikołaj] proponit, si tue benignitatis assuerit consensus [...] hoc in loco claustrum Griseorum tua auctoritate iniciare ${ }^{34}$.

Bliżej przekazu Księgi henrykowskiej był Jan Długosz. Wedle kanonika krakowskiego Mikołaj dokonał fundacji dzięki: consensu et annuentia Ducis Henrici cum barba ${ }^{35}$. Jednak zgoda i przyzwolenie na założenie opactwa w Henrykowie przez Mikołaja nie stanowią dla Długosza argumentu, który przemawiałby za uznaniem księcia za fundatora klasztoru. W porównaniu do Kroniki Książąt Polskich miejsce księcia w przebiegu fundacji jest

29 Marcin Kromer, De origine, s. 188.

30 Joachim Cureus, Gentis Silesise annales, s. 61.

31 Kronika Książąt Polskich, s. 488.

32 Ibidem, s. 547.

33 Liber fundationis, s. 5.

34 Ibidem, s. 7.

35 Ioannis Dlugossii Annales, s. 236. 
mocno ograniczone. Pomimo że postać księcia zostaje przywołana w nocie trzykrotnie (po raz pierwszy przy określeniu Mikołaja jako notariusza księcia Brodatego, następnie w związku z majątkiem, który Mikołaj zdobył na służbie u księcia oraz po raz trzeci, kiedy kronikarz wspomina o zgodzie władcy na fundację), to rola władcy w przebiegu fundacji jest pasywna ${ }^{36}$. Przywołanie postaci księcia Brodatego służy przede wszystkim nadaniu tła działalności Mikołaja, który jako książęcy notariusz był blisko związany z władcą. Być może wynika to z usytuowania opowiadania o Henrykowie w narracji Roczników. Z powodu przyjętej przez Długosza metody prezentacji dziejów, która podporządkowana była chronologicznemu podziałowi na lata, ustęp o klasztorze został oderwany od dziejów panowania Henryka Brodatego, znajdując się m.in. w pod jednym rokiem wraz z fundacją klasztoru w Kacicach przez Iwo Odrowąża ${ }^{37}$. Także w Katalogu biskupów wrocławskich Jan Długosz osłabia pozycję księcia, który występuje w nocie dotyczącej biskupa Wawrzyńca jedynie pośrednio w kontekście urzędu Mikołaja: notario Heinrici cum barba ${ }^{38}$.

$\mathrm{Z}$ jednej strony można mówić o umniejszeniu roli książąt $w$ fundacji opactwa, $z$ drugiej jednak za sprawą przywołania przez Długosza postaci księżnej Jadwigi, znaczenie rodziny książęcej w procesie powstawania opactwa znacząco wzrosło. Mianowicie to przykład pobożnego życia i obyczajów Jadwigi, która cała oddana była miłości ku Bogu, zainspirował Mikołaja do założenia klasztoru ${ }^{39}$. O ile Księga henrykowska wskazywała na impuls, który miał wyjść od samego Boga, który rozpalił w sercu Mikołaja chęć założenia klasztoru, o tyle u Długosza Bóg działa poprzez osobę księżnej ${ }^{40}$. Wiążę się to z jednej strony z niezwykłą czcią, jaką Długosz obdarzał świętych narodu polskiego, z drugiej zaś za inspirację służyła mu Legenda św. Jadwigi.

Maciej z Miechowa oraz Marcin Kromer dość wiernie odtworzyli na kartach swoich kronik relacje łączące Henryka Brodatego z klasztorem henrykowskim. Pierwszy dosłownie przejmuje od Długosza sformułowanie: de consensu et annuentia Ducis Heinrici ${ }^{41}$, zaś Kromer: assentiente Henrico Barbato ${ }^{42}$. Miechowita pozbył się jednak dodatków Długosza, tj. inspiracji notariusza Mikołaja pobożnymi czynami księżnej Jadwigi oraz informacji na temat zbierania majątku przez Mikołaja podczas pracy na rzecz księcia. Podobnie Kromer pominął tą ostatnią informację, zaś element związany z wpływem Jadwigi zastąpił skrótowym zwrotem: Quod exemplum secutus Nicolaus ${ }^{43}$, który odnosi się do informacji poprzedzającej opis fundacji Henrykowa, a mianowicie do założenie Trzebnicy przez Brodatego i jego małżonkę. O ile zaś Miechowita, wzorując się na Długoszu, oderwał opowiadanie o Henrykowie od dziejów panowania Brodatego na rzecz przedstawienia w jednym akapicie najważniejszych fundacji kościelnych I poł. XIII w., o tyle Kromer zamieścił informację o fundacji w ustępie dotyczącym rządów Brodatego, dokładnie zaś pod jego koniec. Nawiązuje tym z jednej strony do modelu prezentowanego w Kronice Książąt Polskich, zaś

\footnotetext{
6 Ibidem.

Ibidem, s. 235.

Catalogus episcoporum Wratislaviensium, s. 461.

Ioannis Dlugossii Annales, s. 236.

Księga henrykowska, s. 3.

Chronica Polonorum, s. 122.

2 De origine et rebus gestis Polonorum libri XXX, s 188.

43 Ibidem.
} 
z drugiej jest to wynik świadomego sposobu prowadzenia wykładu dziejów przez Kromera, który starał się porządkować narracje ${ }^{44}$. Joachim Curreus, wzorując się na Długoszu zarówno pod względem wiadomości, jak i ich układu treści, wprowadził jednak pewne zmiany oraz uzupełnienia. Przede wszystkim u Curreusa znika wzmianka o wyrażeniu przez księcia zgody i przyzwolenia na fundację klasztoru w Henrykowie, co niweluje rolę Henryka Brodatego w całym procesie fundacyjnym. Curreus pozostawił jednak bardziej honorową funkcję księcia, który dał Mikołajowi wraz z innymi panami inspirację do założenia klasztoru: imitatus pietatem sui Principis et multorum aliorum, qui tunc quasi certabant inter sese in condendis monasteriis ${ }^{45}$, co wydaje się być przetworzeniem przez historiografa podobnych ustępów u Długosza, który wspominał o wpływie Iwona Odrowąża oraz księżnej Jadwigi.

$\mathrm{Z}$ drugiej strony Curreus podaje zupełnie nową informację w porównaniu $\mathrm{z}$ wcześniejszymi źródłami. Mianowicie Mikołaj nazwał założony przez siebie klasztor imieniem księcia - Henryków: extruxit coenobium amplium, quod de nomine sui Principis appelavit Henrichovium $^{46}$. Informację tę zna jedynie Księga henrykowska: ob reveranciam domini ducis antiqui appelavit totum Heinrichov ${ }^{47}$. W przekazie Księgi chodzi głównie o terytorium, natomiast Cureus odnosi się do nazwy klasztoru. Wydaje się, że informację tę zaczerpnął bądź to z przekazu ustnego, bądź była to jego próba wyjaśnienia etymologii nazwy klasztoru. Raczej mniej prawdopodobna zdaje się teza o znajomości treści Księgi henrykowskiej, która przypisywała przecież fundację książętom. Pomimo zastosowania przez Cureusa chronologicznego układu tekstu, co potwierdza nadany dziełu tytuł Gentis Sielesiae Annales fundacja klasztoru w Henrykowie została przyporządkowana do części tekstu poświęconej panowaniu Henryka Brodatego: Henricus Barbatus Princeps Silesiae, postea etiam Poloniae ethnarcha ${ }^{48}$.

\section{Mikołaj}

Postać Mikołaja stanowi centralny punkt w opowiadaniu o założeniu Henrykowa we wszystkich przywołanych przez nas źródłach. Zmieniała się jedynie rola Mikołaja w procesie fundacji. Był on albo jedynie przyczyną sprawczą fundacji, albo fundatorem opactwa. Te dwa sposoby postrzegania jego roli w dziejach opactwa w Henrykowie wpływały także na to, w jaki sposób autorzy charakteryzowali postać Mikołaja, a także na ilość zebranych na jego temat informacji.

Przede wszystkim przywoływano funkcję pełnioną przez Mikołaja w kancelarii księcia Henryka Brodatego. Piotr z Byczyny użył najbliższego Księdze henrykowskiej, a także dokumentom z czasów Brodatego sformułowania: Nicolaus notarius ${ }^{49}$, u Długosza mamy secretorum notarius ${ }^{50}$, Miechowita stosuje określenie: ducis notari ${ }^{51}$, Kromer: a secretis

\footnotetext{
44 J. Radziszewska, Warsztat naukowy, s. 143-144.

45 Joachim Cureus, Gentis Silesise annales, s. 61.

46 Ibidem.

47 Liber fundationis, s. 17.

48 Joachim Cureus, Gentis Silesise annales, s. 59-66.

49 Kronika Książat Polskich, s. 488.

50 Ioannis Dlugossii Annales, s. 236.

51 Maciej z Miechowa, Chronica Polonorum, s. 122.
} 
fuit $^{52}$, a Cureus: cancellarius Henrici Barbati ${ }^{53}$. Mimo pewnych drobnych zmian w tytulaturze Mikołaja wszystkie określenia oddają dobrze zakres jego obowiązków w kancelarii księcia Henryka I.

Natomiast aż do Joachima Cureusa żaden z dziejopisarzy nie wspomniał o Mikołaju jako kanoniku wrocławskim: Nicolaus [...], qui fuit canonicus wratislaviensis ${ }^{54}$. Podobną informację podaje także Księga henrykowska: quidem clericus nomine Nicolaum ${ }^{55}$. Autor Księgi henrykowskiej podkreślił również związek Mikołaja z katedrą św. Jana we Wrocławiu, w której to miał on rozpocząć karierę przy boku późniejszego biskupa lubuskiego Wawrzyńca ${ }^{56}$. Dodajmy, że informacja na temat kanonikatu Mikołaja nie znajduje miejsca w żadnym z dokumentów, na zachowanych dyplomach książęcych występował on jedynie jako notariusz. Stąd wydaje się, że Cureus musiał zdobyć tę wiadomość od mnichów. Pytaniem otwartym pozostaje, czy skorzystał z Księgi czy też jej XV-wiecznych streszczeń znajdujących się na osobnych kartach, które podobnie jak Cureus na pierwszym miejscu nazywają Mikołaja kanonikiem wrocławskim ${ }^{57}$. Warto zwrócić uwagę, że Cureus korzystał w swoim dziele dość skwapliwie z archiwaliów miejskich, jak i zbiorów klasztornych ${ }^{58}$, stąd możliwe, że wykorzystał informacje zebrane w Henrykowie.

Nadaniu Mikołajowi rysów osobowych podjął sie Jan Długosz. Dysponując stosunkowo skromnymi danymi na jego temat, głównie za pośrednictwem kroniki Piotra z Byczyny, Długosz przedstawił go jako męża: genere et actione nobilis, co było dość częstym określeniem tegoż dziejopisarza stosowanym wobec fundatorów instytucji kościelnych. Historiograf ukazał także Mikołaja jako człowieka, który naśladował pobożne czyny wielkich mężów. Kończąc opis fundacji klasztoru w Kacicach przez biskupa krakowskiego Iwo Odrowąża i przechodząc do noty na temat fundacji Henrykowa dokonanej przez Mikołaja, dodał: sed neque in solo pontifice Cracoviensi Ywone amor Deo viguisse conspectus est, quin etiam in aliorum cordibus flammam suae dilectionis accendit ${ }^{59}$, co wpisywało się w cel moralizatorski i dydaktyczny Roczników. Przede wszystkim zaś Mikołaj starał sie wzorować czynami swojej księżnej - świętej Jadwigi: Dominae suae ducisse sancte Hedwigis et conversatione edificatus et exemplo, quam calestii amore totam viderat mancipatam ${ }^{60}$. Paralele do Legendy $s ́$ w. Jadwigi były dwie. Tak jak księżna, która założyła z mężem klasztor cysterek w Trzebnicy, tak Mikołaj ufundował Henryków. Po drugie Jadwiga zamieszkała po śmierci męża w ufundowanym przez siebie klasztorze, tak jak i Mikołaj, który nie będąc dostatecznie zadowolonym, tym iż oddał wszystko, co miał Bogu, sam wstąpił w klasztorne mury. Można więc powiedzieć, że Długosz osadził postać Mikołaja w kontekście Legendy św. Jadwigi, co nadawało całej historii fundacji logiczną spójność. Informacje przytoczone przez Długosza z małymi modyfikacjami znalazły odzwierciedlenie u kolejnych dziejopisarzy. Maciej z Miechowa przedstawił postać Mikołaja identycznie jak Długosz, jedynie usunął fragment

52 Marcin Kromer, De origine et rebus gestis Polonorum libri XXX, s 188.

53 Joachim Cureus, Gentis Silesise annales, s. 61.

54 Ibidem.

55 Liber fundationis, s. 2.

${ }_{56}$ Księga henrykowska, s. 2-3.

57 Liber fundationis, s. 137-146.

58 M. Karpowska-Jarczyk, op.cit., s. 116-117.

59 Ioannis Dlugossii Annales, s. 236.

${ }^{60}$ Ioannis Dlugossii Annales, s. 236. 
o inspiracji św. Jadwigą i Iwonem Odrowążem. Marcin Kromer nazwał Mikołaja: vir nobilis et locuples ${ }^{61}$. Skrócił i zmodyfikował nieco również fragment dotyczący wzorowania się notariusza Mikołaja postacią św. Jadwigi, zawierając całość przekazu Długosza w słowach: Quod exemplum secutus, co miało związek z poprzedzającą opis Henrykowa, informacją o fundacji Trzebnicy przez Henryka Brodatego i Jadwigę ${ }^{62}$. Można więc powiedzieć, że Kromer zmienił przy okazji nieco sens Roczników, gdyż odseparował całość opowiadania o Mikołaju od legendy jadwiżańskiej, a także wprowadził Henryka Brodatego obok małżonki do grona inspiratorów Mikołaja. Joachim Cureus postać Mikołaja określił skrótowo: homo nobilis $^{63}$. Zachował także podobnie jak Kromer fragment dotyczący czerpania wzorców przez Mikołaja, jednak całkowicie zniknęła z jego opowiadania postać Jadwigi, zastąpiona przez Henryka Brodatego oraz: miltorum aliorum, qui tunc quasi certabant inter sese in candendis monasteriis ${ }^{64}$, co odwołuje się z pewnością do następującej po Henrykowie nocie o założeniu klasztoru w Świdnicy przez braci z rodziny Wierzbnów, a także nawiązuje do wzmianki Długosza o wpływie pobożnych fundacji Iwona Odrowąża ${ }^{65}$.

Jan Długosz jako pierwszy starał się wyjaśnić dalsze losy notariusza Mikołaja po założeniu klasztoru w Henrykowie. Mikołaj, nie będąc ukontentowany swoimi dotychczasowymi pobożnymi czynami, postanowił: locum eciam ipsum spreto seculo ingressus, asumpto habitu, in ordine usque ad mortem felix fundator militavit ${ }^{66}$. Notariusz Mikołaj wedle autora Roczników wstąpił do klasztoru, przyjął mnisi habit i służył w nim aż do śmierci. Już wcześniej sugerowaliśmy, że passus ten wiążę się z losami św. Jadwigi, którą naśladował Mikołaj. Informacja o przyjęciu przez Mikołaja habitu i służbie do końca życia w klasztorze henrykowskim nie znajduje potwierdzenia we wcześniejszych źródłach. Księga henrykowska nie wspomina nic na ten temat, choć jakiś ślad można by dostrzec we wzmiance opata Piotra-autora I części Księgi na temat pobożnego życia Mikołaja: Sed licet vir iste non in religiositate aliqua exemplum vivendi preberet [...] videbatur interius ad instar cuiusdam margarite per quatuor angulos lucidissime fulgentis adornari ${ }^{67}$. Ponadto opat Henryk miał namawiać Mikołaja, by ten pozwolił pochować się w murach klasztoru, zaś w chwili śmierci notariusz został zaopatrzony przez opata henrykowskiego wiatykiem i innymi kościelnymi sakramentami ${ }^{68}$. Fragmenty te mogą sugerować, że ostatnie dni życia Mikołaj spędził w klasztorze. Ponadto w dokumentach biskupa Tomasza I z 1237 oraz 1263 r. znajduje się wyrażenie quasi haberat capellanus eorum Nicolaus ${ }^{69}$. Jako że Mikołaj był kanonikiem wrocławskim, prawdopodobnie z święceniami kapłańskimi, mógł więc w klasztorze sprawować funkcje kapłańskie. Oba dokumenty znajdują się jednak w klasztornym kopiarzu, z którego Długosz wedle dotychczasowych badań nad Rocznikami nie korzystał.

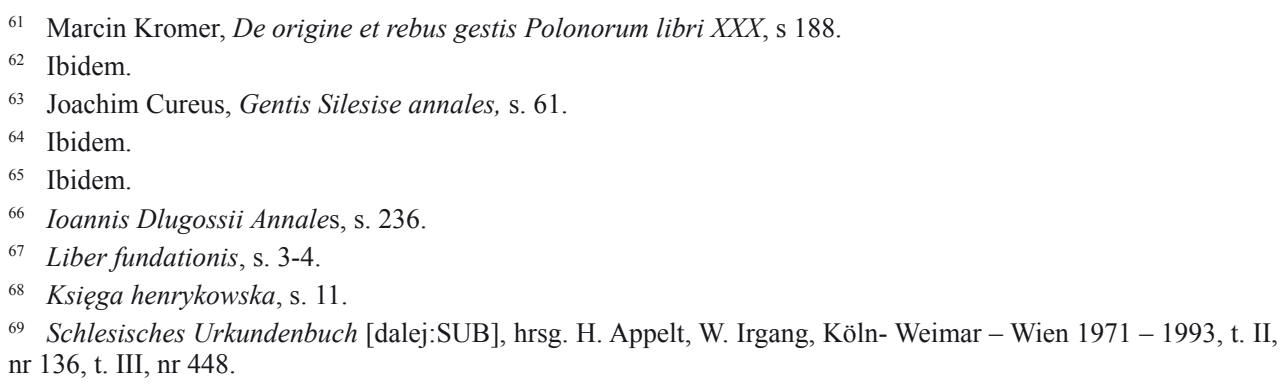


Informację o schyłku życia Mikołaja przejęły wszystkie kolejne źródła. Miechowita powtórzył dokładnie opowiadanie Długosza. Kromer pod nieco odmienną stylistycznie wersją pisał: ipse quoque ibi religionum professus, vitam peregit ${ }^{70}$. Natomiast Joachim Cureus dostarczył nowych wiadomości na temat końca życia Mikołaja: Tandem cum sibi nondum satisfacerat, ipse etiam religionem illam, quae est Cisterciensium, ingressus est. Annotarunt alii, istum Nicolaum quarto anno post in vita sua sacerdotali non vero monastica, emigrasse, sed in talibus non est res magni momenti ${ }^{71}$. W pierwszym zdaniu mamy niemal dosłowne zapożyczenie z Długosza. W drugiej części mamy za to nową informację, iż Mikołaj zmarł w klasztorze po czterech latach, a także poprawkę wiadomości Długosza dotyczącej mnichostwa notariusza Mikołaja. Mianowicie miał on umrzeć jako duchowny, a nie mnich. Cureus dokładnie zaznaczył, że korzystał z dodatkowych źródeł: annotarunt alii.

W tym miejscu należy uczynić pewną dygresję dotyczącą mnichostwa Mikołaja. August Sartorius- historiograf zakonu cysterskiego w swoim dziele Cistercium bis-tertium przywołał informację dotyczącą przyjęcia przez Mikołaja ślubów zakonnych ${ }^{72}$, powołując się w tym na dzieła Caspara Jongelinusa oraz Angela Manrique ${ }^{73}$. Skonsultował jednak sprawę z ówczesnym przeorem Henrykowa Tobiaszem Ackermanem, który miał stwierdzić, że: De Viri monachatu nil meminerint, illud solum innuentes, eundem non in monasterio, sed in coemiterio ecclesiae cathedralis wratislaviensis, uni canonicum, extiterat sepultum equiscere ${ }^{74}$. W samym klasztorze wydaje się, że znano wersję o mnichostwie Mikołaja. W nowożytnych notach dołączonych do Księgi henrykowskiej znajdziemy informacje: etiam anno [1227. przyp.MM] obiit idem Nicolaus Henrichovius, postquam quingenium vel sexenium in religione transegisset, oraz in eodem monasterio religionum professus, vitam peregit, ${ }^{75}$ co jest jednak niemal dosłownym powtórzeniem fragmentu kroniki Marcina Kromera ${ }^{76}$.

Jak widzimy, informacja ta nie wyszła z klasztoru henrykowskiego. Pierwszy raz została przywołana przez Długosza, a następnie była przejmowana przez kolejnych dziejopisarzy. Można więc domniemywać, że Cureus skorzystał z materiałów klasztornych: Księgi henrykowskiej, bądź jej streszczeń. Przeciw szukaniu źródła tej wiadomości w tradycji ustnej, zastanej wśród henrykowskich mnichów świadczy przede wszystkim odwołanie się Cureusa do źródeł pisanych. Tezę tę potwierdza także czas, jaki Mikołaj miał jeszcze żyć po fundacji Henrykowa - quarto anno post, co jeśli przyjąć za punkt wyjścia rok 1222, daje nam w przybliżeniu rok 1226/1227, co zgadza się z informacją Księgi henrykowskiej.

\section{Uposażenie klasztoru}

Uposażenie klasztoru w Henrykowie w świetle powyższych źródeł zostało opisane nader zdawkowo. Piotra z Byczyny temat ten w ogóle nie interesował. Dopiero Długosz starał się uzupełnić tą lukę. Wedle autora Roczników Mikołaj zgromadził spory majątek, służąc księciu Brodatemu jako notariusz. Klasztor założył: in villa patrimonii sui Henrichov, nadał

\footnotetext{
70 Marcin Kromer, De origine et rebus gestis Polonorum libri XXX, s 188.

71 Joachim Cureus, Gentis Silesise annales, s. 61.

72 A. Sartorius, Cistercium bis - tertium seu Historia elogialis [...], s. 1117- 1118, Praga 1700.

73 Ibidem.

74 Ibidem.

75 Liber fundationis, s. 146.

76 Marcin Kromer, De origine et rebus gestis Polonorum libri XXX, s 188: ipse quoque ibi religionum professus, vitam peregit.
} 
mu zaś: tam villa eadem, quam alias ad illum locum spectantibus dotat ${ }^{77}$. W porównaniu do opisu opactwa w Trzebnicy, czy Kacic/Mogiły widać, że autor nie dysponował szczegółowymi informacjami na temat uposażenia, co zaznacza się ogólnym stwierdzeniem, że opactwo zostało obdarowane wieloma posiadłościami. Ciekawy wydaje się jednak passus związany ze statusem samego Henrykowa. Mianowicie Długosz stwierdza, że Henryków był dziedzicznym majątkiem notariusza ${ }^{78}$, co odbiega od przekazu Księgi henrykowskiej, w której to Mikołaj przedstawiony jest jako przybysz z Małopolski, który ziemie zgromadził aktami kupna i z nadań książęcych ${ }^{79}$. Jednak Henryków jako patrimonium opisuje źródło współczesne fundacji Henrykowa: dokument Władysława Odonica z $1225 \mathrm{r}^{80}$ Rodzi się jednak pytanie czy Długosz korzystał z dokumentu Odonica, w którym książę nadał ziemie w ziemi nakielskiej pod kolonizację klasztorom w Lubiążu oraz Henrykowie, czy też był to raczej domysł własny autora, który uznał za prawdopodobne, że Mikołaj mógł nadać opactwu swoją ojcowizną. Z braku wzmianek Długosza na temat owego nadania na kartach Roczników należałoby się przychylić do tej drugiej możliwości.

Identycznie o uposażeniu klasztoru pisał Maciej z Miechowa. Podobnie Marcin Kromer: et ipse patrimonium suum omne Cistersciensibus monachis [...] donavit ${ }^{81}$. Z kolei Cureus w ogóle nie zamieścił w swoich rocznikach wzmianki o statusie ziem Mikołaja. Dość lakonicznie wspomniał jedynie, że notariusz Mikołaj: praedia sua, que habebat ditissima legavit ad cultum divinum ${ }^{82}$.

W związku z informacją Długosza o dziedzicznym statusie Henrykowa Mikołaj otrzymał od kronikarza określenie: de Henrichow ${ }^{83}$, zaś Marcin Kromer urobił z tego przydomek dla notariusza Henryka Brodatego, nieco na modłę renesansową: Nicolaus Henrichovius ${ }^{84}$. Jedynie Piotr z Byczyny oraz Joachim Cureus nie zastosowali podobnych określeń.

\section{Data fundacji}

Jednym z najciekawszych elementów przedstawienia dziejów Henrykowa jest data fundacji. W tej materii Księga henrykowska dostarcza bardzo dokładnych informacji. Na jej kartach pojawiają się aż trzy daty: 1222 r., kiedy to zapadła decyzja o fundacji opactwa, 28 maja 1227-przybycie pierwszego konwentu mnichów oraz 6 czerwca 1228 - oficjalna fundacja klasztoru, jak i poświecenie ołtarzy w kościele klasztornym ${ }^{85}$.

Piotr z Byczyny w głównym toku narracji Kroniki Książąt Polskich nie podaje daty fundacji klasztoru. Natomiast w De institucione pod sylwetką biskupa Wawrzyńca autor zamieszcza datę przybycia do Henrykowa pierwszego konwentu: cuius temporibus fundatum est monasterium Cisterciensis ordinis in Henrichow, per quedam Nicolaum, qui dicitur fuise notarius domini Henrici cum barba, ducis Wratislaviensis, cum adiutorio tamen eisudem domini sui duci. Conventus intravit idem monasterium sub duce predicto anno domini MCC

77 Ioannis Dlugossii Annales, s. 236.

78 Ioannis Dlugossii Annales, s. 236.

79 Księga henrykowska, s. 2-3.

80 SUB, t. I, nr 252.

81 Marcin Kromer, De origine et rebus gestis Polonorum libri XXX, s 188.

82 Joachim Cureus, Gentis Silesise annales, s. 61.

83 Ioannis Dlugossii Annales, s. 236.

84 Marcin Kromer, De origine et rebus gestis Polonorum libri XXX, s 188.

85 Księga henrykowska, s. 9, 11. 
XXII, V kalend. Juni ${ }^{86}$. Jak widzimy data dzienna 28 maja (V kalendy czerwca) jest zgodna z stanem rzeczywistym, jednak wątpliwość budzi data roczna - 1222. Jako, że zapis dotyczący biskupa Wawrzyńca wykazuje niemal identyczną zbieżność z sylwetką tegoż biskupa z Ordynacji biskupów wrocławskich, który znajduje się w Księdze henrykowskiej: Huius domini Laurentii episcopi tempore fundatum est claustrum nostrum de Heinrichow, anno domini MCCXXVII sub pio duce Heinrico, cognomine cum barbato. Eodem anno quinto kalendas Junii, intravit conventus hic in Henrichow ${ }^{87}$, wydaje się więc, że autor popełnił błąd przy korzystaniu z henrykowskiego katalogu. Po pierwsze przemawia za tym umieszczenie poprawnej daty dziennej, po drugie zaś ewidentne wzorowanie się na katalogu z Henrykowa. Pomimo, że rok 1222 pojawia się w historii fundacji klasztoru, to można by go pomylić bardziej z datą fundacji klasztoru aniżeli z przybyciem pierwszego konwentu.

Określenie daty założenia klasztoru sprawiało dziejopisarzom, ale także samym cystersom często wiele problemów. Kapituła Generalna zakonu starała się uregulować ów problem, ustalając, że za datę fundacji uznany ma być moment przybycia pierwszego konwentu, liczącego 12 braci na czele $\mathrm{z}$ opatem ${ }^{88}$. Jednak użycie przez kronikarza poprawnej daty dziennej sugeruje raczej nie tyle świadome przyjęcie przez Piotra daty 1222 jako lepiej odpowiadającej momentowi fundacji (jeżeliby miał on przyjąć za moment fundacji wyrażenie woli jej powołania), a raczej zwykły błąd. Warto przywołać uwagę Odilo Schmidta, który analizując śląskie katalogi biskupów wrocławskich, wskazał na podobny przykład błędu przy dacie śmierci biskupa Cypriana ${ }^{89}$. Część katalogów zamiast roku 1207 zamieszczała informację o jego śmierci pod rokiem $1202^{90}$. Błąd ten miał jednak ogromne znaczenie dla dalszych przekazów na temat klasztoru w Henrykowie. Tę samą datę przyjął Zygmunt Różyc w swojej Cronica et numerus episcoporum wratislaviensium stanowiącej streszczenie Kroniki Książąt Polskich, opisując sylwetkę biskupa Wawrzyńca dodał także fakt fundacji Henrykowa: cuius temporibus fundatum est monasterium Heinrichau. A.D. $1222^{91}$.

Jan Długosz biernie powtórzył błąd kanonika brzeskiego. W dodatku usunął datę dzienną, którą zawarł w swoim katalogu Piotr z Byczyny. Datę fundacji Henrykowa Długosz włączył także w logiczny ciąg wydarzeń. W tym samym roku ufundowany został klasztor cystersów w Kacicach przez biskupa krakowskiego Iwona Odrowąża, którego to przykład miał wpłynąć na decyzję założenia klasztoru przez notariusza Mikołaja: sed neque in solo pontifice Cracoviense Ywone amor dei viguisse conspectus est, quin eciam in aliorum cordibus flammam suae dilectionis accendit ${ }^{92}$.

Maciej z Miechowa tradycyjnie przejął za Długoszem datę fundacji klasztoru. Natomiast u Marcina Kromera brakuje daty. Jak już wcześniej wspomnieliśmy wiadomość o fundacji klasztoru w Henrykowie znajduje się w akapicie dotyczącym ostatnich lat rządów Henryka

\footnotetext{
86 Kronika Książąt Polskich, s. 547.

87 Liber fundationis, s. 126.

88 W. Schulte, Die Nachrichten der Cistercienser über Leubus, „Zeitschrift des Vereins für Geschichte Schlesiens", 33/1899, s. 213-214, s.222.

89 O. Schmidt, Untersuchungen zu den Breslauer Bischofskatalogen, Breslau 1917, s. 45. Możliwe, że autor źle odczytał datę roczną z henrykowskiego katalogu. W XIII w. liczbę dwa zapisywano za pomocą skośnej kreski skierowanej w lewo i daszkiem nad nią. Natomiast siedem kształtem przypominała odwróconą do góry literę $\mathrm{v}$.

90 Ibidem.

91 Cronica et numerus episcoporum wratislaviensium, wyd. W. Kętrzyński, MPH, t. VI, Kraków 1893, s. 578.

92 Ioannis Dlugossii Annales, s. 236.
} 
Brodatego między założeniem prze tegoż władcę klasztoru mniszek w Trzebnicy (1203), a fundacją klasztoru dominikanek w Rybniku (między 1202 a 1211), zaś w samym akapicie autor wymienia dalsze fundacje, co nie naprowadza na datę fundacji Henrykowa ${ }^{93}$. Przyjmując, że Kromer opierał się w powyższej części swojego dzieła głównie na Rocznikach Długosza ${ }^{94}$, zaś w pozostałych elementach noty o Henrykowie nie zmienił żadnej z informacji, można zakładać, że również w kwestii daty nie miał innego źródła. Podobny problem z datowaniem powstania klasztoru w Henrykowie znajdziemy u Joachima Cureusa. Śląski dziejopisarz odnotował założenie klasztoru henrykowskiego pod rokiem $1221^{95}$. Jednak pomieścił w nim dwa wydarzenia. Pierwszym z nich są klęski elementarne, które nawiedziły ziemie polskie i miały trwać jeszcze przez trzy kolejne trzech lata: Anno 1221. et triennio proximo post dicitur in omnibus his regionibus favisse fames et pestilentia atrocissima ${ }^{96}$. Dopiero na drugim miejscu odnotował założenia klasztoru w Henrykowie: Eodem tempore quidam Nicolaus [...] extruxit coenobium ${ }^{97}$. Widać więc wyraźnie, że Cureus nie przypisywał założenia klasztoru bezpośrednio do roku 1221, gdyż rok ten nie dość, że dotyczył głównie zarazy i głodu na ziemiach całej Polski, to jeszcze miał trwać przez trzy lata, zaś do fundacji klasztoru miało dojść: eodem tempore, czyli między 1221 a 1224 r.

Porównując do rozkładu rocznych informacji z Roczników Jana Długosza, które stanowiło dla śląskiego historiografa jedno z podstawowych źródeł wiedzy, zobaczymy, że Cureus połączył w jednym akapicie kilka informacji, które autor Roczników zawarł między rokiem 1221 oraz 1222. Śląski historiograf zebrał pod rokiem informacje o głodzie i zarazie, które nawiedziły ziemie polskie. Pod tym samym rokiem znajdziemy je wyłożone u Długosza. Następnie zaś wyselekcjonował z noty kanonika krakowskiego dotyczącej powstania kościoła parafialnego w Krakowie w 1222 r. wiadomość o kontynuacji klęsk żywiołowych ${ }^{98}$. Z kolei bezpośrednio pod 1222 r. Cureus zawarł nieznaną Długoszowi informację o wyprawie pruskiej książąt polskich ${ }^{99}$. Można więc sądzić, że Cureus nie wyznaczył żadnej nowej interpretacji daty założenia klasztoru. W kwestii przypisania powstania opactwa w Henrykowie do roku 1221 przywołajmy pokrótce wyniki badań Leopolda Janauschka ${ }^{100}$. Wedle badań tegoż data ta pojawiła się szczególnie w nowożytnych dziełach historiograficznych. Szczególnie zaś informacja ta został spopularyzowana przez prace cysterskiego dziejopisarza Caspara Jongelinusa.

Dla przykładu dodajmy, że przyporządkowanie powstania klasztoru w Henrykowie do roku 1221 r. można spotkać również w źródłach proweniencji krzeszowskiej m.in. w klasztornej kronice z II poł. XVII w. ${ }^{101}$, w której to zapis na temat opactwa henrykowskiego jest

\footnotetext{
93 Marcin Kromer, De origine et rebus gestis Polonorum libri XXX, s. 188.

94 J. Radziszewska, Źródla Marcina Kromera do dzieła De origine et rebus gestis Polonorum libri XXX, „Studia Warmińskie", 26/1989, s. 228.

95 Joachim Cureus, Gentis Silesise annales, s. 61.

96 Ibidem.

97 Ibidem.

98 Ioannis Dlugossii Annales, s. 233, 235, 239.

99 Joachim Cureus, Gentis Silesise annales, s. 62.

${ }^{100}$ L. Janauschek, Originum Cisterciensium Tomus Primus in quo praemissis congregationum domiciliis adjectisque tabulis chronologico-genealogicis veterum abbatiarum a monachis habitatarum fundationes ad fidem antiquissimorum fontium primus descripsit, Wiedeń 1877, s. 229-230.

101 Archiwum Państwowe we Wrocławiu, Akta klasztoru cystersów w Krzeszowie, Kronika klasztoru w Krzeszowie od Henryka Pobożnego, syg.1, s. 21.
} 
jednak wierną kopią odpowiedniego ustępu z dzieła Jongelinusa: Notitia abbatarium ordinis cistertiensis ${ }^{102}$.

\section{Podsumowanie}

W analizowanym przez nas materiale źródłowym znalazły się zasadniczo dwie koncepcje fundacji henrykowskiej. Pierwsza z nich reprezentowana przez Piotra z Byczyny przypisywała tytuł fundatora klasztoru księciu Henrykowi Brodatemu, co było częściowo zgodne $\mathrm{z}$ promowaną $\mathrm{w}$ samym opactwie henrykowskim metryką książęcej fundacji. Natomiast druga, której autorem był Jan Długosz uznawała za założyciela opactwa notariusza Mikołaj. W późnośredniowiecznym i wczesnonowożytnym dziejopisarstwie przeważyła koncepcja Jana Długosza ${ }^{103}$. Kolejni historiografowie: Maciej z Miechowa, Marcin Kromer, Joachim Cureus przejmowali z większymi czy mniejszymi zmianami przekaz krakowskiego kronikarza. Dopiero XVII w. kompendia historyczne dotyczące zakonu cystersów autorstwa Manrique, Jongelinusa, Sartoriusa, a także praca badawcza Mikołaja Henelego von Henenfelda przywróciła na karty wersję o książęcej fundacji Henrykowa.

\section{The State of Knowledge about the Beginnings of the Cistercian Monastery in Henryków in Historiography of the late Middle Ages and Renaissance Summary}

The cloister of Cistercians in Henryków possesses the complex founding traditions, both monastic and secular. The most complete vision of the origins of the monastery in Henryków gives us the Book of Henryków. The Book of Henryków delivers quite a complicated picture of the foundation. In the foundation of the cloister as many as three persons took part: the notary Nicholas, prince Henry the Bearded and Henry the Pious. According to the author of the first part of the Book of Henryków, the prince Henry the Pious was the only founder of the cloister. The analysis of late medieval and renaissance chronicles give us a quite different picture of its foundation. There are two leading concepts. The first sustained thesis of princely foundations. Its originator was Peter of Byczyna the author of the Chronica Principium Poloniae. The second concept was created by Jan Dlugosz, who ascribed the foundation of Henryków to the notary Nicholas.

Keywords: monastery in Henryków, historiography of the late Middle Ages and Renaissance, the Henryków Book, transmission of knowledge.

Nota o Autorze: Monika Michalska, doktorantka w Instytucie Historii Uniwersytetu Jagiellońskiego. Zainteresowania badawcze: historia Zakonu Cysterskiego w Polsce, tradycje fundacyjne klasztorów cysterskich na Śląsku, Księga henrykowska, recepcja dzieł historiograficznych w opactwach cysterskich.

\footnotetext{
102 C. Jongelinus, Notitia abbatarium ordinis cistertiensis [...], Kolonia 1640, s. 53.

103 St. Cynarski, Uwagi nad problemem recepcji „Historii” Jana Dlugosza w Polsce XVI i XVII wieku, w: Dlugossiana: studia historyczne w pięćsetlecie śmierci Jana Dlugosza, red. St. Gawęda, Kraków 1980, s. 281-291.
} 